\title{
APPLICATION FOR SIMULATING GYRO-COMPASS BEHAVIOR
}

\begin{abstract}
Resolution of International Maritime Organization (IMO Res. A.424 (XI)), International Convention for the Safety of Life at Sea (SOLAS V/19.2.5) and consequently 'Provisions Survey of Ships Marine', part V, contained in the Polish Register of Shipping impose an obligation to fit ships with gyro-compass as one of the most complex marine equipment has found in the curricula of seafarers at the operational level (IMO Model Course 7.03). Curriculum involves the use real navigation devices. In addition, the adaptation of teaching facilities to meet the needs of the training process often requires the development of educational aids in the form of simulators and applications that represent the construction and operation of navigation devices. The article presents possibilities of the application gyro-compass simulator developed for the requirements of the Institute of Navigation and Maritime Hydrography PNA. Among others, the program is used to simulate the conditions in which you can expect the occurrence of different types of gyro-compass deviation. Designed software is expected to improve the educational process, to help the students assimilate the content of the curriculum in the field of classic gyro-compasses and familiarize trainees with static and dynamic errors occurring with the change of operating conditions.
\end{abstract}

\section{Keywords:}

gyro-compass, compass error, process simulation.

\section{INTRODUCTION}

According to the International Convention for the Safety of Life at Sea, SOLAS, Rule 19, p. 2.1.1 all ships irrespective of the tonnage should have 
properly compensated magnetic compass or device independent of the power supply, determining course of the vessel and allow readability on the bridge. However, the magnetic compass was reliable device until the beginning of steel ships construction. Iron as the main material of construction, the increasing number of electrical conductors affected the reduce utility of magnetic compasses. An alternative solution was gyro-compass. Operating principle of the gyro-compass, opportunities, errors, methods of correction are the focus of the lectures and laboratories in training centers and maritime universities, specifically navigation departments. According to the curriculum and the specification card of navigation devices, listeners learn the construction, operation and accompanying potential sources of gyro-compass errors. Additionally, the program of seafarers training at the operational level IMO Model Course 7.03 provides teaching the theory of gyro systems, and errors resulting from service of devices with solutions based on the gyro theory. During the activities of navigation devices, students acquire practical abilities i.e. launch the equipment, periodic service and determining the gyro deviation and compensation. Part of the classes is conducted using actual devices. However, in order to better assimilate the contents of the curriculum, it is recommended to develop devices simulating the gyro-compass operation. Accordingly, there are requirements to develop an application explaining principle of operation and complying with the IMO Res. A.424 (XI). Taking into account external conditions, software should present gyro-compass errors distinguishing between static and dynamic deviation components.

\section{STATE OF KNOWLEDGE ON EXISTING APPLICATIONS SIMULATING GYRO-COMPASS BEHAVIOUR}

Accordance with the provisions of the STCW Convention (International Convention on Standards of Training, Certification and Watchkeeping), the training program for seafarers at the operational level (IMO Model Course 7.03) it is expected that the classes held in training centers cover the issues related to the gyro-compass theory. These issues apply to the free gyroscope theory, external forces acting on the gyroscope in cardan suspension, transformation free gyro to gyro-compass, gyro-compass errors, methods for accelerated introduction of the main gyro axis in position of meridian, cooperation gyro-compass with radar and VHF/UHF RDF (Radio Direction Finder). Part of the subjects is realized in the form of lectures, 
classes and laboratories, with the use educational aids in the form of the free gyro, classic gyro-compass or using applications that simulate gyro-compass. During laboratory classes, Transas NaviTrainer 5000 simulator is used. Tasks simulator are intended to develop the skills and habits in determining the gyro-compass error, speed deviation and inertial deviation. Less expensive is application construction with capabilities of device simulation and determining errors. The example is an application developed by Maciej Gucma, Jakub Montewka, Antoni Zieziula from Szczecin Maritime University. The authors implemented an application for laboratory classes. The purpose of the application is simulating gyro-compass, preparation for operating and the simulation of errors based on the hydrometeorological, geographic conditions, course and speed.

\section{BRIEF DESCRIPTION — THE ESSENCE OF SOLUTION}

Project concerns a laboratory simulation affecting the indications of two gyro-compass and adaptation equipment for didactical purpose of 'navigation devices'. The laboratory consists of the following components (Fig. 1):

- notebook with the installed Microsoft EXCEL 2013 with support for macros and VBA (Visual Basic for Applications) components;

- software with VBA components for simulating environmental conditions;

- printer connected to the computer for printing test results;

- cable set.

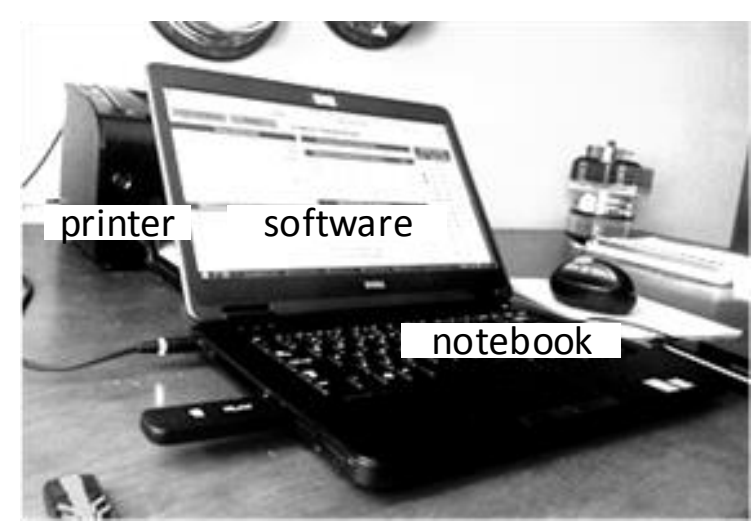

Fig. 1. The laboratory simulation of conditions affecting the indications course 
Application is designed for students. Author applied a simple form of application development. The use of components of MS EXCEL with support for macros and VBA produces a similar final result compared to applications developed by 'Delphi' or 'Lazarus' builder.

The application has been designed to print the results of a classical laboratory report (Fig. 2).

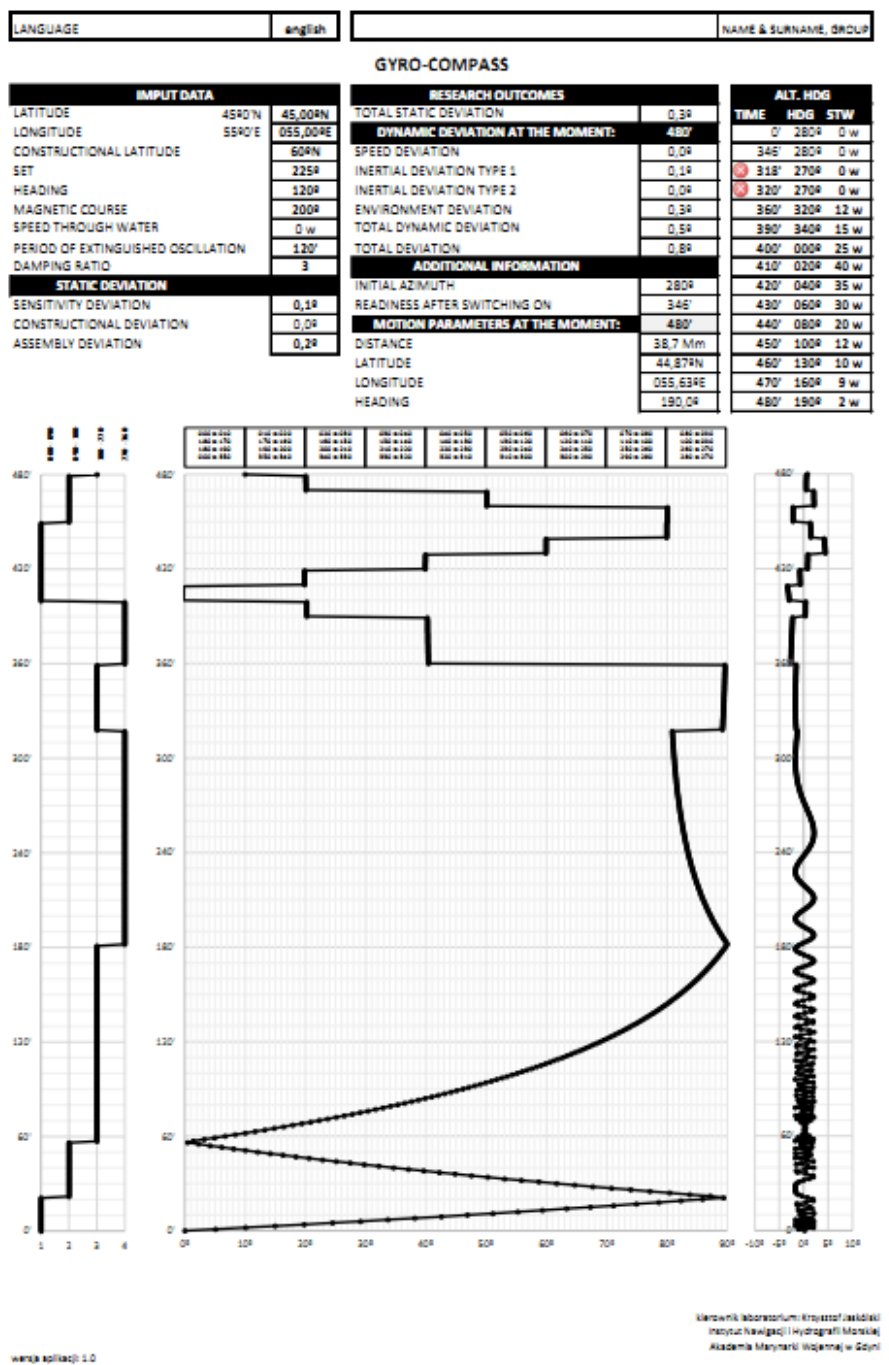

Fig. 2. Print of the laboratory results 


\section{The purpose of executing an application}

\section{to simulate gyro errors}

- understanding principles of the internal correction gyro-compass;

- understanding the processes occurring during gyrocompass launch and setting the main axis of the gyroscope in the meridian plane, the gyroscope precession;

- familiarization with the principle of determine the gyro course;

- understanding the factors affecting the gyro-compass accuracy, components of dynamic and static deviation.

\section{Description of designed application}

Prior to the implementation of the laboratory student is required to read the information contained in one of the bookmark application. In bookmark: gyro-compass work rules, theory of free gyroscope motion, rules of behavior under the action of external force (force moment), the gyroscope behavior on earth globe, the main axis gyroscope fluctuations, gyro-errors and their methods of elimination were presented.

Upon successful completion of the test laboratory student proceeds to task. He starts the application, selects language in which the content will be presented and enter the name (Fig. 3).

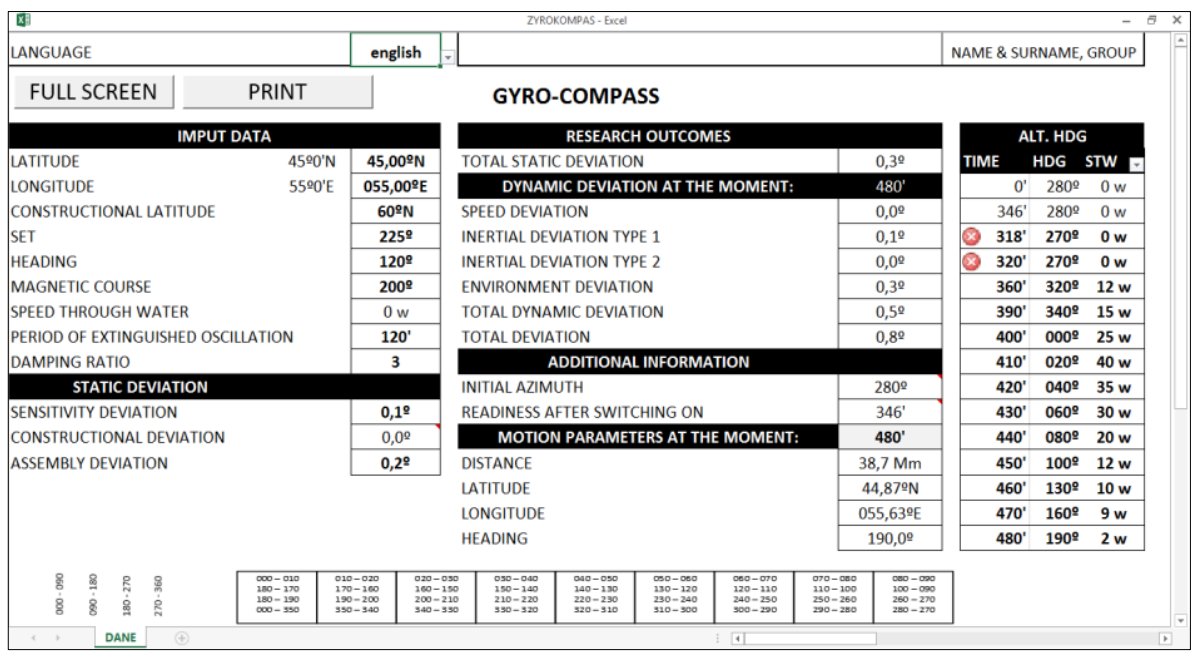

Fig. 3. Part of the application responsible for data input and test results presentation at any time during gyro-compass operation 
Subsequently, student introduces 'Input data': geographical position, constructional latitude, wave direction, an initial gyro course before starting device and magnetic course to determine the initial azimuth, period of extinguished oscillation, damping ratio, as shown in Figure 4. It is possible filling the fields with bold type. Other fields have been blocked.

\begin{tabular}{|c|c|c|}
\hline \multicolumn{3}{|l|}{ IMPUT DATA } \\
\hline LATITUDE & $45 \div 0 \mathrm{~N}$ & $45,009 \mathrm{~N}$ \\
\hline LONGITUDE & $55^{\circ} 00^{\prime} \mathrm{E}$ & $055,00 \div \mathrm{E}$ \\
\hline CONSTRUCTIONAL LATITUDE & & $609 \mathrm{~N}$ \\
\hline SET & & 2259 \\
\hline HEADING & & 120 은 \\
\hline MAGNETIC COURSE & & 2009 \\
\hline SPEED THROUGH WATER & & $0 \mathrm{w}$ \\
\hline PERIOD OF EXTINGUISHED OSCILLATION & & $120^{\prime}$ \\
\hline DAMPING RATIO & & 3 \\
\hline
\end{tabular}

Fig. 4. Imput data

It is assumed, during application run the speed is set to 0 knots. Course does not change. Then, student set static deviation according to Figure 5.

\begin{tabular}{|l|c|}
\hline \multicolumn{1}{|c|}{ STATIC DEVIATION } & $\mathbf{0 , 1} \stackrel{ }{ }$ \\
\cline { 2 - 2 } SENSITIVITY DEVIATION & $0,0 \mathbf{0}$ \\
\cline { 2 - 2 } CONSTRUCTIONAL DEVIATION & $\mathbf{0 , 2} \mathbf{\circ}$ \\
\hline
\end{tabular}

Fig. 5. Static deviation components

The comments included maximum and minimum values of input data. Then, student enters the course, moment of alteration course and speed through water for the 13 scheduled courses according to the content of laboratory instructions (Fig. 6).

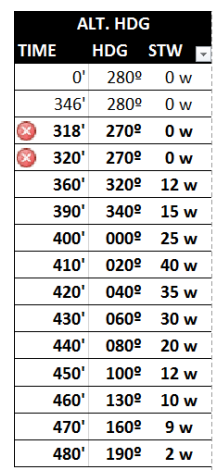

Fig. 6. Aleteration course and speed 
It should be noted to enter time exceeded value indicated in the 'readiness after switching on' (Fig. 7).

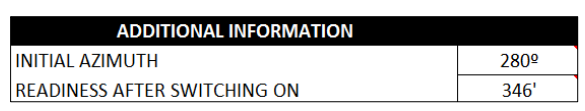

Fig. 7. Presentation of additional information

If one enters a value less than the time available for work, then there is a red pictogram X (Fig. 6). Then, input value exceed the time required to run gyro-compass. Time is associated with the initial azimuth. If you get azimuth $<0.5^{\circ}$, gyro-compass will indicate readiness to work. Initial azimuth is determined from the difference of gyro and magnetic course.

Additionally, the application enables the ship motion parameters at the moment $t_{i}$ (Fig. 8). By typing operation time in a gray field, one gets the following information: distance, position, and gyro course.

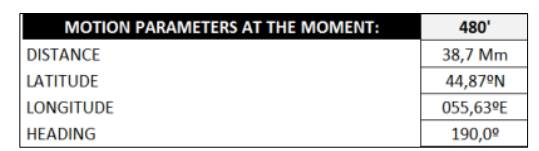

Fig. 8. Ship motion parameters at the moment $t_{i}$

Method of determining components affecting the gyro compass errors were presented in [Posiła, Szybka, 2006]. Mathematical counting was applied to estimate the distance. If one inputs: coordinates of the initial position, gyro course, traveled distance, an application determines the arrival coordinates (task outright). The task has been solved by the average latitude methodology. For this purpose, the 'triangle navigation methodology' is used. The methodology is presented in [Urbański et al., 2000].

Gyro-compass errors are presented in bookmark 'research outcomes' and 'dynamic deviation at the moment $t_{i}$ ' (Fig. 9).

\begin{tabular}{|l|c|}
\hline \multicolumn{2}{|c|}{ RESEARCH OUTCOMES } \\
\hline TOTAL STATIC DEVIATION & $0,3^{\circ}$ \\
\hline \multicolumn{1}{|c|}{ DYNAMIC DEVIATION AT THE MOMENT: } & $480^{\circ}$ \\
\hline SPEED DEVIATION & $0,0^{\circ}$ \\
\cline { 2 - 2 } INERTIAL DEVIATION TYPE 1 & $0,1^{\circ}$ \\
\cline { 2 - 2 } INERTIAL DEVIATION TYPE 2 & $0,0^{\circ}$ \\
\cline { 2 - 2 } ENVIRONMENT DEVIATION & $0,3^{\circ}$ \\
\cline { 2 - 2 } TOTAL DYNAMIC DEVIATION & $0,5^{\circ}$ \\
\cline { 2 - 2 } TOTAL DEVIATION & $0,8^{\circ}$ \\
\hline
\end{tabular}

Fig. 9. Research outcomes at the moment $t_{i}$ 


\section{Course recorder}

An application is equipped with the course recorder. This is a device responsible for graphic presentation of gyro course (Fig. 10). The grid of transverse and longitudinal parallel lines is applied on paper tape. On the left side five vertical lines is located. Four lines limit the field in the quarter system (000-090, 090-180, 180-270, 270-000). A quarter scriber moves within these limits. Further part paper tape is divided into 90 equal parts. Each part corresponds to the angle $1^{\circ}$. The longitudinal lines are described at $10^{\circ}$. Angles grow to the right for the first and third quarters, and grow to the left for the second and fourth quadrants. Gradual scriber moves over the width of the paper tape. The interval between adjacent transverse lines is 10 minutes. Transverse lines are described every 10 minutes. On the right side five lines every $5^{\circ}$ are plotted. Within the limits $\left(-10^{\circ}, 10^{\circ}\right)$ scriber moves to present the total deviation gyro-compass. Course recorder presents eight hours of operation.
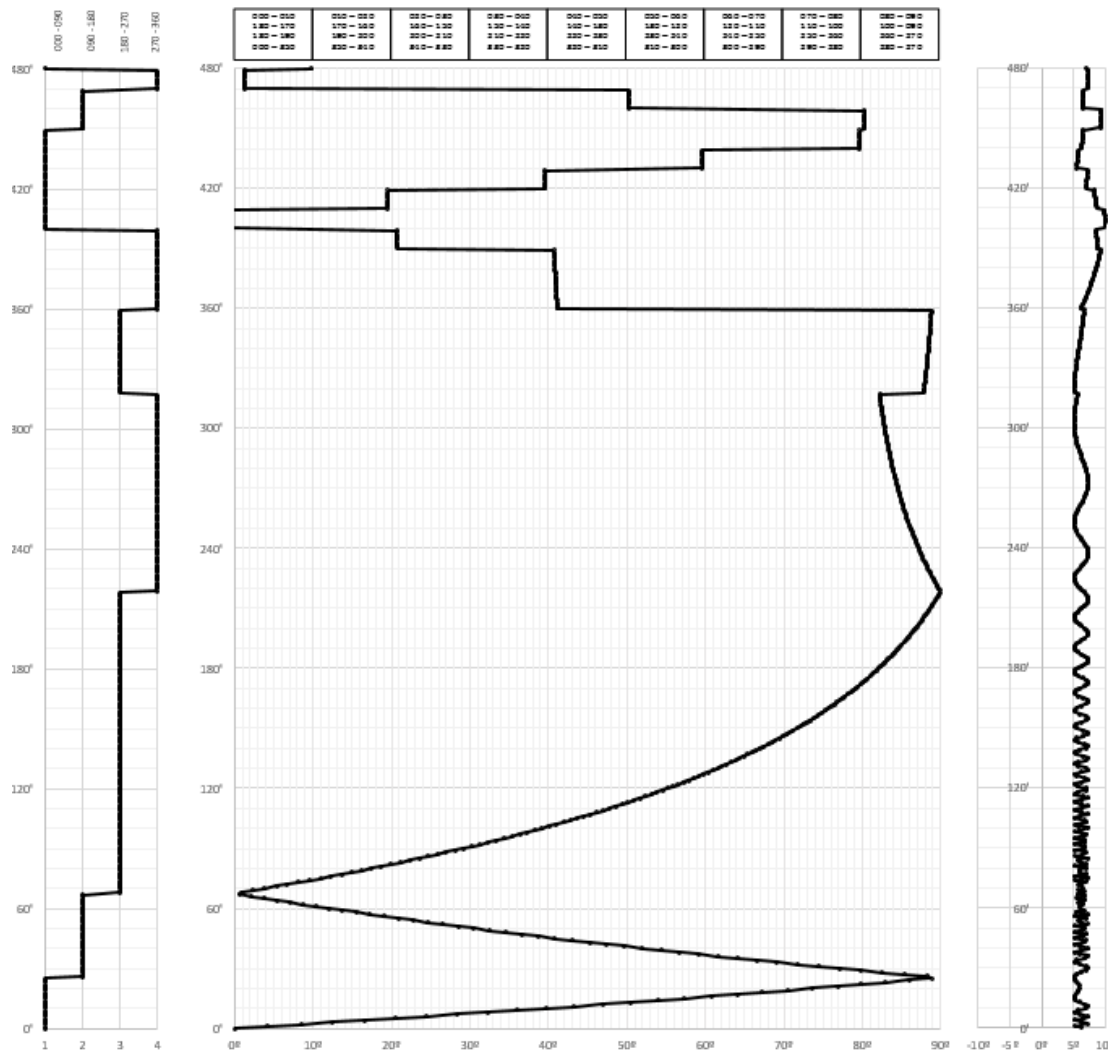

Fig. 10. Course recorder 
Additionally, the application is equipped with two buttons: 'FULL SCREEN' and 'PRINT'. Student, after completing the tasks is obliged to print laboratory report.

\section{GYRO-COMPASS ERRORS}

On the basis of the input data, compass errors are obtained:

1) components of static deviation:

- sensitivity deviation,

- assembly deviation;

2) components of dynamic deviation:

- speed deviation,

- inertial deviation type 1 ,

- inertial deviation type 2 .

\section{Total deviation}

Total deviation is the sum of errors affecting the accuracy of gyro-compass. Total deviation is a sum of static deviation $\delta_{s t}$, whose value does not depend on the basic gyro-compass motion and dynamic deviation $\delta_{d}$ depends on the basic gyro-compass motion relative to the Earth's surface [Posiła, Szybka, 2006].

$$
\delta_{c}=\delta_{s t}+\delta_{d}
$$

where:

$\delta_{c}-$ total deviation,

$\delta_{s t}-$ static deviation,

$\delta_{d}-$ dynamic deviation.

Static deviation determines the relationship [Posiła, Szybka, 2006]:

$$
\delta_{s t}=\delta_{c z}+\delta_{o}+\delta_{k}+\delta_{m}
$$

where:

$\delta_{c z}$ - sensitivity deviation - the smallest change of course, resulting in gyro-compass reaction $\left(0,05^{\circ}-0,1^{\circ}\right)$,

$\delta_{o} \quad$ - readout deviation — eliminated through the use of digital display, 
$\delta_{k}$ - constructional deviation - depends on latitude, does not occur in two gyroscopic compass,

$\delta_{m}$ - assembly deviation - results from transfer of the $\mathrm{X}$ axis compass to the vessel longitudinal axis.

Dynamic deviation determinates relationship:

$$
\delta_{d}=\delta_{v}+\delta_{i}+\delta_{\dot{s}}
$$

where:

$\delta_{v}$ - speed deviation,

$\delta_{i}$ - inertial deviation,

$\delta_{\text {ś }}$ - environmental deviation.

Speed deviation $\delta_{v}$ - error triggered the ship motion and determine the relationship [Posiła, Szybka, 2006]:

$$
\operatorname{tg} \delta_{v}=-\frac{v \cdot \cos K R}{R \cdot \omega \cdot \cos \varphi+v \cdot \sin K R}
$$

where:

$v \quad$ - speed through water,

$R$ - Earth radius, according to WGS-84: $\mathrm{R}=6378135,6 \mathrm{~m}$

$\omega$ - ship angular velocity,

$\varphi$ - latitude,

$K R$ - true course.

Assuming that:

$$
\mathrm{KR}=\mathrm{K} \dot{\mathrm{Z}}-\delta_{v}
$$

and

$$
\sin \delta_{v} \cong \delta_{v}
$$

After transformations we get the form:

$$
\delta_{v}{ }^{\circ}=-\frac{v[k n] \cdot \cos K \dot{Z}}{900[k n] \cdot \cos \varphi} 57,3,
$$

where:

$K \dot{\mathrm{Z}} \quad$ - gyro course,

$v[k n] \quad$ - speed (knots),

$900[k n]$ - linear velocity of point on the Earth's equator:

$$
R \cdot \omega=900 \mathrm{kn} \text {. }
$$


Inertial deviation type $1 \delta_{i}^{\mathbf{1}}$ this gyro error inducted by ship motion in latitude other than constructional latitude $\varphi_{0}$. Inertial forces resulting from the change in velocity will change the position of meridian causing speed deviation according to [Posiła, Szybka, 2006]:

$$
\Delta \delta_{v}=\delta_{v 2}-\delta_{v 1}
$$

where:

$\delta_{v 1}$ - speed deviation before course alteration,

$\delta_{v 2}$ - speed deviation after course alteration.

One obtains:

$$
\begin{aligned}
& \delta_{v 1}{ }^{\circ}=-\frac{v_{1}[k n] \cdot \cos K \dot{\mathrm{Z}}_{1}}{900[k n] \cdot \cos \varphi_{1}} 57,3 ; \\
& \delta_{v 2}{ }^{\circ}=-\frac{v_{2}[k n] \cdot \cos K \dot{\mathrm{Z}}_{2}}{900[\mathrm{kn}] \cdot \cos \varphi_{2}} 57,3 .
\end{aligned}
$$

The maximum value of inertial deviation is achieved immediately after course alteration, which is calculated from the relationship:

$$
\delta_{i}^{1}=\left(\delta_{v 2}-\delta_{v 1}\right)\left(\frac{\cos \varphi}{\cos \varphi_{0}}-1\right)
$$

where:

$\varphi_{0}$ - constructional latitude.

Inertial deviation type $2 \delta_{i}^{2}$ arrise as a result of at the inertial force during the ship motion. Also called the suppression deviation. Then, after 20-22 minutes after the end of the maneuver the $\mathrm{X}$-axis is achieved the greatest deviation from the meridian. In this moment the second type of inertial deviation disappears. Deviation is in the range of $3^{\circ}-5^{\circ}$. Deviation is largest during altering course form $000^{\circ}$ to $180^{\circ}$ at high speed [Posiła, Szybka, 2006].

To prevent the deviation, electromagnetic suppression switch is applied in a gyro sphere. Its task is to interrupt oil flow between cells just before course or speed alteration.

Environmental deviation (wave deviation) $\delta_{f}$ depends on the wave direction - drift $\left(\sin 2 K R_{f}\right)$. It is greatest at the inter-cardinal directions, i.e. NE, SE, SW, NW. At the wave direction N, E, S, W is absent. 
Wave deviation is given by formula [Posiła, Szybka, 2006]:

$$
\delta_{f}=-\frac{B \cdot j^{2}}{4 H \cdot g^{2} \cdot \cos \varphi} \sin 2 K R_{f} .
$$

Granted that:

$$
B=m \cdot g \cdot a
$$

and

$$
j=l \cdot \omega_{f}^{2},
$$

where:

$B$ - maximum moment of gravity force,

$H$ - kinetic moment,

$j \quad$ - amplitude of acceleration bias,

$l$ - the amplitude of the gyro linear displacement in the horizontal plane of the line $Z Z$,

$\omega_{f}$ - angular frequency bias.

and

$$
\omega_{f}=2 \pi \cdot T_{f}
$$

where:

$T_{f}$ - bias period.

\section{SIMULATION OF GYRO-COMPASS ACTIVATION}

To simulate launch gyrocompass, it was assumed that:

- period of extinguished oscillation $T_{G}=110 \mathrm{~min}$;

- damping ratio $f=3,(2,5-6)$;

- $K K=020^{\circ}$;

- $K \dot{Z}=200^{\circ}$

- difference between gyro and magnetic oscillation $180^{\circ}$, it means, initial azimuth $\alpha_{0}=180^{\circ}$.

- During gyro-compass activation: $t_{0}=0 \mathrm{~min}$, azimuth $\alpha_{0}=180^{\circ}$.

- After: $t_{1}=\frac{T_{G}}{2}$, i.e. $t_{1}=55 \mathrm{~min}$, azimuth $\alpha_{1}=\frac{180^{\circ}}{3}=060^{\circ}$.

- After $t_{2}=T_{G}$, i.e. $t_{2}=110 \mathrm{~min}$, azimuth $\alpha_{2}=\frac{060^{\circ}}{3}=020^{\circ}$. 
- After $t_{3}=\frac{3}{2} T_{G}$, i.e. $t_{3}=165 \mathrm{~min}$, azimuth $\alpha_{3}=\frac{020^{\circ}}{3}=006,7^{\circ}$.

- After $t_{4}=2 T_{G}$, i.e. $t_{4}=220 \mathrm{~min}$, azimuth $\alpha_{4}=\frac{006,7^{\circ}}{3}=002,2^{\circ}$.

- After $t_{5}=\frac{5}{2} T_{G}$, i.e. $t_{5}=275 \mathrm{~min}$, azimuth $\alpha_{5}=\frac{002,2^{\circ}}{3}=000,7^{\circ}$.

Gyro-compass is ready to work after $275 \mathrm{~min}$, i.e. after $4 \mathrm{~h} 35 \mathrm{~min}$. This period is variable value and depends on initial azimuth [Posiła, Szybka, 2006].

\section{CONCLUSION}

The project of the laboratory will improve the teaching process and training of students in the principles of preparation for activation, determining the total deviation of the gyro-compass. Designed laboratory complements the educational process in the theory of classical gyro-compass. During laboratory classes, participants become familiar the factors having a direct impact on the gyro-compass accuracy. Course recorder will allow additional analysis of gyro-compass errors according to speed, wave direction, latitude and constructional latitude. Change of damping ratio and period of extinguished oscillation have a significant impact on extension or reduction of readiness to work, with the required accuracy compatible with the IMO Res. A.424 (XI). The application provides the ability to calculate total deviation at any operation time in laboratory.

Graphical presentation of total deviation is an innovative solution, not used in gyro-compasses equipped with gyro course recorder.

\section{REFERENCES}

[1] Gucma M., Montewka J., Zieziula A., Mechanism of action and the service of gyro-compasses [in Polish], exercise No. 1, IIRM, AM, Szczecin 2005.

[2] IMO Model Course 7.03, Officer in charge of a navigational watch, Sub-Committee on Standards of Training and Watchkeeping, London 1999.

[3] IMO Res. A.424 (XI), Performance Standards for Gyro-Compasses, London 1979.

[4] Posiła J., Szybka P., Classical gyroscopic compasses with the internal correction [in Polish], AMW, Gdynia 2006.

[5] Urbański J., Kopacz Z., Posiła J., Marine Navigation [in Polish], part II, AMW, Gdynia 2000. 
Received October 2016

Reviewed December 2016

\section{KRZYSZTOF JASKÓLSKI}

Polish Naval Academy

Śmidowicza 69 Str., 81-127 Gdynia, Poland

e-mail: k.jaskolski@amw.gdynia.pl

\section{STRESZCZENIE}

Obowiązek wyposażenia jednostek pływających w urządzenia żyrokompasowe reguluje rezolucja Międzynarodowej Organizacji Morskiej (IMO Res. A.424 (XI), międzynarodowa konwencja o bezpieczeństwie życia na morzu (SOLAS V/19.2.5) i w konsekwencji zawarte w Polskim Rejestrze Statków „Przepisy nadzoru konwencyjnego statków morskich", cz. V. Tematyka dotycząca kompasów żyroskopowych jako jednych z najbardziej złożonych urządzeń okrętowych znalazła miejsce w programach nauczania kadr morskich na poziomie operacyjnym (IMO Model Course 7.03). Program szkolenia przewiduje wykorzystanie faktycznych urządzeń nawigacyjnych. Dodatkowo dostosowanie bazy dydaktycznej do potrzeb procesu szkolenia często wymaga opracowania pomocy naukowych w postaci symulatorów i programów przedstawiających budowę i zasadę działania urządzeń nawigacyjnych. Artykuł prezentuje możliwości aplikacji symulującej kompas żyroskopowy, opracowanej na potrzeby Instytutu Nawigacji i Hydrografii Morskiej AMW. Program służy między innymi do symulowania warunków, w jakich można spodziewać się występowania różnych typów dewiacji żyrokompasowych. Zaprojektowane oprogramowanie ma uskutecznić proces dydaktyczny, pomóc słuchaczom przyswoić treści programowe z zakresu klasycznych kompasów żyroskopowych oraz zapoznać szkolonych z błędami statycznymi i dynamicznymi pojawiającymi się wraz ze zmianą warunków pracy urządzenia. 